\title{
Research on the Effectiveness of Chinese Graduate Funding Policy Based on Degree Type
}

\author{
Cui Shiyu ${ }^{1}$ \\ ${ }^{1}$ Graduate School, Capital University of Economics and Business, Beijing 100070, China

\begin{abstract}
Based on the policy texts and survey data, this paper analyzed the issue of graduate funding in different types of graduates from different levels. The study found that the current state-level graduate funding policy grants different funding treatments to graduates of different degrees. In university-level, academic and professional degree masters face different funding requirements. There are obvious differences in the degree of funding for graduates of different degree types in personal level. Academic masters not only have lower tuition fees than professional masters, but also receive a higher percentage and amount of total funding than professional masters.
\end{abstract}

Keywords: graduate funding, graduate education, degree type

\section{BACKGROUND AND LITERATURE REVIEW}

At present, China's graduate funding is changing from guaranteed funding to development funding, which means that the number of funding projects is increasing, the income group is expanding, and the funding methods are diversifying. The effectiveness of funded projects is receiving increasing attention.

However, there is not much research on this issue. It mainly focuses on the following aspects: First, the evolution of the graduate funding system[1]. Second, it discusses the problems existing and countermeasures in the current graduate funding system[2]. Third, a small number of scholars have empirically researched the funding of graduate students in some regions or universities[3].

Some basic issues have not yet been discussed, including the effectiveness of the aim of graduate funding policies. This issue will affect the future demand for graduate education.

Based on the above analysis, this study attempts to analyse the implementation of graduate funding in China's universities from the national, universities, and individual levels using a policy-oriented analysis framework. Based on a review of China's graduate funding policies and a systematic quantitative analysis, this paper intends to answer the following research questions:(1)What are the current guarantee standards and coverage of graduate funding? (2)Is funding at the national, universities and individual levels consistent? (3)How effective is the aim of graduate funding and are there differences in degree types?

\section{GRADUATE FUNDING SYSTEM-- NATIONAL LEVEL}

Since 2014, China has fully implemented a graduate education fee system, charging tuition fees to all newly admitted graduate students included in the national graduate admissions program. There is no difference in the tuition policy for professional masters and academic masters at the national level.

At present, the Chinese government has established a relatively complete funding policy system at the stage of graduate education. As shown in Table 1.

In 2018 , the number of students assisted reached 2.03 million, and the average student subsidy was about 6,600 yuan. Graduate funding has become one of the important financial supports for students from low-income families to complete their studies.

In 2018 , the number of students assisted reached 2.03 million, and the average student subsidy was about 6,600 yuan. Graduate funding has become one of the important financial supports for students from low-income families to complete their studies. 
Table 1 China's graduate funding system $(2018)$

\begin{tabular}{|c|c|c|c|c|c|}
\hline & \multicolumn{5}{|c|}{ FUNDING POLICY TOOL } \\
\hline & \multicolumn{3}{|c|}{ Gift type } & \multirow{2}{*}{$\begin{array}{c}\begin{array}{c}\text { Reward } \\
\text { type }\end{array} \\
\\
\text { Graduate } \\
\text { assistants } \\
\text { allowanc } \\
\text { e }\end{array}$} & \multirow{2}{*}{$\begin{array}{c}\begin{array}{c}\text { Repayme } \\
\text { nt type }\end{array} \\
\text { The } \\
\text { National } \\
\text { Student } \\
\text { Loan } \\
\text { Policy }\end{array}$} \\
\hline & $\begin{array}{c}\text { Graduat } \\
\mathrm{e} \\
\text { national } \\
\text { scholar } \\
\text { ships }\end{array}$ & $\begin{array}{c}\text { Graduat } \\
\text { e } \\
\text { academ } \\
\text { ic } \\
\text { scholar } \\
\text { ships }\end{array}$ & $\begin{array}{c}\text { Graduat } \\
\text { e } \\
\text { Nationa } \\
1 \text { Grants }\end{array}$ & & \\
\hline \multicolumn{3}{|c|}{ FUNDING CROWD } & \multicolumn{3}{|c|}{$\begin{array}{l}\text { all include full-time graduate } \\
\text { students }\end{array}$} \\
\hline SCALE & 35 & 1654 & 2042 & 2410.8 & l \\
\hline AMOUN & 0.7 & 11.69 & 13.7 & 6.909 & I \\
\hline $\begin{array}{l}\text { CRITE } \\
\text {-RIA }\end{array}$ & $20 \mathrm{k}$ & $\leq 12 \mathrm{k}$ & $\geq 6 \mathrm{k}$ & $\begin{array}{c}\text { distinctiv } \\
\mathrm{e}\end{array}$ & $12 \mathrm{k}$ \\
\hline \multicolumn{3}{|c|}{$\begin{array}{l}\text { DEGREE CATEGORY } \\
\text { DIFFERENCES }\end{array}$} & \multicolumn{3}{|c|}{ not exist } \\
\hline
\end{tabular}

(Unit: thousand people, billion yuan) Graduate national scholarships are used to reward graduates who have completed outstanding academic, scientific research, and social welfare activities, with outstanding results, outstanding results, and outstanding performance. Each year, 35,000 graduate students are awarded. The standard is 20,000 yuan per student per year. Degree difference.

Graduate academic scholarships are assessed based on factors such as graduate academic performance, scientific research results, social services, and family economic status, with no difference in degree type.

Graduate National Grants covers all full-time graduate students in the National Graduate Admissions Program. The funding standard is no less than 6000 yuan per student per year, and there is no difference in degree type.

Graduate assistants allowance is for full-time graduate students, and there is no difference in degree types. Among them, the research assistantship subsidy is mainly paid through the labor service expenses and scientific research indirect expenses in the funding of scientific research projects, and the funds required for the teaching assistantship and management assistantship allowance are borne by colleges and universities. The standard of the allowance is reasonably determined in combination with factors such as local price levels.

The National Student Loan Policy includes fulltime graduate students. There is also no difference in degree type [4].

At the national level, professional masters are given the same funding policies as academic masters. It can be said that the national level pays more attention to the construction of the graduate funding system rather than the differences among internal groups.

\section{THE PRACTICE OF GRADUATE FUNDING SYSTEM- - UNIVERSITY LEVEL}

The state actually devolves the right of grants to universities. Universities can independently adjust and tilt the categories and proportions of graduate grants in light of their own circumstances. In other words, in the actual operation of graduate funding, various regions and colleges and universities should formulate their own policies according to local conditions. So, in order to study the actual distribution of current graduate funding, this article selected four universities located in Beijing and Shanghai, and summarized the analysis results in Table 2.

Table 2 Tuition and funding of sample institutions

\begin{tabular}{|c|c|c|c|c|c|c|}
\hline \multicolumn{7}{|c|}{ BASIC SITUATION OF THE UNIVERSITY } \\
\hline \multirow{2}{*}{\multicolumn{3}{|c|}{$\begin{array}{c}\text { Area } \\
\text { University }\end{array}$}} & \multicolumn{2}{|c|}{ BEIJING } & \multicolumn{2}{|c|}{ SAHNGHAI } \\
\hline & & & A & $\mathrm{B}$ & $\mathrm{C}$ & $\mathrm{D}$ \\
\hline \multicolumn{3}{|c|}{ Types } & DFC & general & DFC & general \\
\hline \multicolumn{7}{|c|}{ TUITION POLICY } \\
\hline \multicolumn{3}{|c|}{ Academic Masters } & $8 \mathrm{k}$ & $8 \mathrm{k}$ & $8 \mathrm{k}$ & $7 \mathrm{k}$ \\
\hline \multicolumn{3}{|c|}{ Professional Masters } & $\begin{array}{c}8 \mathrm{k}- \\
286 \mathrm{k}\end{array}$ & $8 \mathrm{k}-76 \mathrm{k}$ & $\begin{array}{l}15 \mathrm{k}- \\
388 \mathrm{k}\end{array}$ & $\begin{array}{l}10 \mathrm{k}- \\
38 \mathrm{k}\end{array}$ \\
\hline \multicolumn{3}{|c|}{$\begin{array}{c}\text { Degree Category } \\
\text { Differences }\end{array}$} & \multicolumn{4}{|c|}{ exist } \\
\hline \multicolumn{7}{|c|}{ FUNDING POLICY } \\
\hline \multirow{6}{*}{ 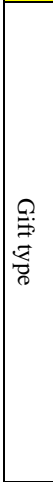 } & Gradu & Standard & \multicolumn{4}{|c|}{$20 \mathrm{k}$} \\
\hline & $\begin{array}{c}\text { ate } \\
\text { nation } \\
\text { al } \\
\text { schola } \\
\text { rships }\end{array}$ & Ded & \multicolumn{4}{|c|}{ not exist } \\
\hline & \multirow{2}{*}{\begin{tabular}{|c|} 
Gradu \\
ate \\
acade \\
mic \\
schola \\
rships
\end{tabular}} & Standard & $8 \mathrm{k}-12 \mathrm{k}$ & $4 \mathrm{k}-1 \mathrm{k}$ & $8 \mathrm{k}$ & $1 \mathrm{k}-8 \mathrm{k}$ \\
\hline & & Ded & exist & $\begin{array}{l}\text { not } \\
\text { exist }\end{array}$ & exist & $\begin{array}{l}\text { not } \\
\text { exist }\end{array}$ \\
\hline & \multirow{2}{*}{$\begin{array}{l}\text { Gradu } \\
\text { ate } \\
\text { Nation } \\
\text { al } \\
\text { Grants } \\
\end{array}$} & Standard & $6 \mathrm{k}$ & $7 \mathrm{k}$ & $6 \mathrm{k}$ & $9.6 \mathrm{k}$ \\
\hline & & Ded & exist & $\begin{array}{l}\text { not } \\
\text { exist }\end{array}$ & not exist & $\begin{array}{l}\text { not } \\
\text { exist }\end{array}$ \\
\hline \multirow{2}{*}{ 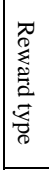 } & \multirow{2}{*}{$\begin{array}{c}\text { Gradu } \\
\text { ate } \\
\text { assista } \\
\text { nts } \\
\text { allowa } \\
\text { nce } \\
\end{array}$} & Standard & $\begin{array}{l}2.4 \mathrm{k}- \\
6.4 \mathrm{k}\end{array}$ & $\begin{array}{l}5.6 \mathrm{k}- \\
6.4 \mathrm{k}\end{array}$ & $3.6 \mathrm{k}$ & $8 \mathrm{k}$ \\
\hline & & Ded & \multicolumn{4}{|c|}{ not exist } \\
\hline \multirow[b]{2}{*}{ 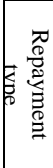 } & The & Standard & $12 \mathrm{k}$ & $12 \mathrm{k}$ & $12 \mathrm{k}$ & $10 \mathrm{k}$ \\
\hline & $\begin{array}{l}\text { Nation } \\
\text { al } \\
\text { Studen } \\
\text { t Loan } \\
\text { Policy }\end{array}$ & Ded & \multicolumn{4}{|c|}{ not exist } \\
\hline
\end{tabular}

('DFC' for Double First-Class universities; 'Dcd' for Degree category differences Unit: yuan) 
To be specific: (1) there is no difference in degree types among Graduate national scholarships, Graduate assistants allowance and The National Student Loan Policy. (2) There are differences in the Graduate assistants allowance. The funding standards of general universities are slightly higher than those of 'Double First-Class' universities. (3) The implementation of Graduate academic scholarships differs in the types of degrees in 'Double First-Class' universities, but not in general universities. (4) There is a degree difference in the Graduate National Grants. Although A University does not allow professional masters to apply for academic scholarships, the Graduate National Grants and scientific practice innovation awards are for professional masters only. This also reflects the high degree of freedom of key universities in the formulation and implementation of funding policies. (5) Professional graduate students charge higher tuition fees than academic masters.

\section{THE PRACTICAL TARGETING EFFECT OF GRADUATE FUNDING POLICY - PERSONAL LEVEL}

The data used in this section are from the data submitted by 10 sample universities in BEIJING FUNDING SYSTEM (2019). The basic conditions of tuition and funding are shown in Table 3.

Table 3 Status of funding for graduate students in Beijing (10 sample universities) in 2019

\begin{tabular}{|c|c|c|c|c|c|}
\hline & Type & $\begin{array}{l}\text { Professional } \\
\text { Masters }\end{array}$ & $\begin{array}{c}\text { Academic } \\
\text { Masters }\end{array}$ & Master & $\begin{array}{l}\mathrm{D} \\
\mathrm{cd}\end{array}$ \\
\hline & Tuition fee & 29048.25 & 7690.42 & 20550.09 & *** \\
\hline 0 & $\begin{array}{c}\text { Proportion of } \\
\text { funding received }\end{array}$ & $81.50 \%$ & $89.40 \%$ & $85.06 \%$ & ** \\
\hline 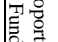 & Gift type & $76.20 \%$ & $86.90 \%$ & $81.02 \%$ & $\begin{array}{l}* * * \\
*\end{array}$ \\
\hline 洁 & Repayment type & $8.02 \%$ & $7.78 \%$ & $7.91 \%$ & $*$ \\
\hline & Reward type & $32.50 \%$ & $58.71 \%$ & $44.29 \%$ & $\begin{array}{l}* * * \\
*\end{array}$ \\
\hline & $\begin{array}{l}\text { The total amount } \\
\text { of funding }\end{array}$ & 10429 & 13600 & 12508 & $\begin{array}{l}* * \\
*\end{array}$ \\
\hline 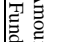 & Gift type & 6311 & 7054 & 6780 & $\begin{array}{c}* * \\
*\end{array}$ \\
\hline 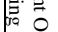 & Repayment type & 1658 & 1582 & 1624 & $*$ \\
\hline & Reward type & 2460 & 4964 & 4104 & ** \\
\hline
\end{tabular}

Judging from the proportion of graduate students receiving funding: (1) Tuition fees for professional masters are significantly higher than academic masters. (2) The coverage of professional masters is significantly lower than that of academic masters. (3) Except for the difference in degree coverage of repayment type, the coverage of the other two types of professional masters is significantly lower than that of academic masters. Judging from the amount of funding: In 2019, the total funding for professional masters $(10,429$ yuan) was significantly lower than academic masters (13,600 yuan). Similarly, among various types of grants, professional masters are slightly higher than academic masters (1582 person-years) in the amount of Repayment type funding (1658 yuan per person year), but the difference is not significant. The amount of grants and remuneration (the main source of graduate funding, $87 \%$ ) for professional masters is significantly lower than for academic masters.

\section{CONCLUSION AND SUGGESTION}

This article reviews the graduate funding policy in China, and analyses the allocation of Chinese graduate funding to different degree types of graduates from the current national design, University practice, and personal acquisition. The policy text and real data are analysed. Combined with the full text analysis, the main research conclusions are as follows:

First, the current target of graduate funding in China includes both academic masters and professional masters. However, compared to academic masters, the funding system for professional graduates in China is very imperfect, lacking a more reasonable and complete funding system, and there is no significant difference in the funding policy for professional masters and academic masters at the national level. National level funding policies for professional masters are often formulated with reference to academic master funding policies. At the national level, professional masters and academic masters are treated equally, and professional masters are given the same funding policies as academic masters. It can be said that the national level pays more attention to the construction of the graduate funding system rather than the differences among internal groups.

Second, there are large differences in the practice of graduate funding systems in different colleges. The state actually delegates the right of grants to universities, and universities can independently adjust and tilt the categories and proportions of graduate grants in light of their own circumstances. In the actual operation of graduate funding, 
Students [J]. Degree and Postgraduate Education, 2006 (7): 40-43.

[3] Li Wenli, Yang Xi. Professional Differences of Graduate Funding from the Perspective of Educational Benefits [J]. Peking University Education Review, 2011, 9 (1): 53-67.

[4]Ministry of Finance of the People's Republic of China, National Development and Reform Commission, Ministry of Education. Opinions on improving the input mechanism of graduate education [EB / OL].

[5]Wu Binzhen and others. The effect of the policy on poverty and scholarships for college students [J]. Financial Research, 2011 (12): 47-61. There is a large gap in the awards for graduates with different training models. The full-time master's degree award system needs to be developed and constructed. The two most important projects in graduate funding are awards and bursaries[5], namely awards and poverty alleviation. The policy objective of rewards such as scholarships is to reward graduate students with outstanding grades, so academic performance and scientific research should be factors influencing the availability of this type of funding. The goal of poverty funding is to help the poor, and its audience should be graduate students from lowincome families, so it should be affected by the family's economic situation. The results of this article indicate that the effectiveness of funding policy targeting seems to depend more on the implementation of the funding policy itself. The analysis of the implementation of funding policies should be strengthened in the subsequent policy implementation.

\section{ACKNOWLEDGMENT}

This work was supported by GRADUATE EDUCATION REFORM PROJECT of Capital University of Economics and Business. I am deeply indebted to all the other teachers in Graduate School for their direct and indirect help to me.

\section{REFERENCES}

[1] Shen Yanbing, Shang Lingyu, Tao Dekun. Thoughts on improving the graduate funding system [J]. Liaoning Education Research, 2004 (11): 41-44.

[2] $\mathrm{Xu}$ Gang, Li Yanfang. Some Thoughts on Improving National Student Loans for Graduate 